\title{
Patient selection - clinical and imaging criteria - for percutaneous lung malignancies ablation: a single centre experience and a literature review
}

\author{
Carrafiello $\mathrm{G}^{1 \star}$, Nocchi Cardim L ${ }^{1}$, Floridi $C^{1}$, Piacentino $\mathrm{F}^{1}$, Di Massa $\mathrm{A}^{1}$, Ierardi $\mathrm{AM}^{1}$ and Fugazzola $\mathrm{C}^{1}$ \\ Correspondence: gcarraf@gmail.com \\ ${ }^{1}$ Department of Radiology, Vascular and Interventional Radiology, University of Insubria, Varese, Italy.
}

\begin{abstract}
Purpose: To settle the most important clinical and radiological selection criteria for percutaneous ablation in patients with pulmonary tumours.

Materials and Methods: A retrospective analysis of pulmonary thermal ablations performed in our Centre with special "focus" on clinical and radiological selection criteria for thermal ablation. The criteria employed in our Centre were then compared with those of 24 studies chosen from Literature that fit the issue and described their patient selection criteria for lung tumours thermal ablation.

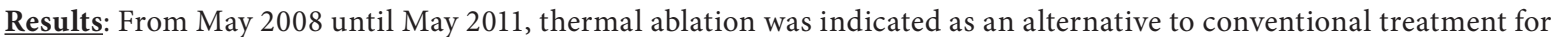
32 patients (20 males e 12 females) with NSCLC in different stages, with medium age of 71 years old (range 46 - 82). Inoperability was a condition established for all patients, for their clinical conditions, especially poor lung function, for the disease extension, as a controlled metastasis, and/or for their diameter and localization, as lesions in proximity to heart, large vessels and trachea.

Conclusion: Thermal ablation is a rational alternative for conventional therapy in an adequately selected group of patients. A randomized controlled study with a control group submitted to conventional therapies to define with precision the candidable patients to thermal ablative therapy would be necessary.
\end{abstract}

Keywords: selection criteria, lung malignancies, ablation techniques, microwave ablation, radiofrequency ablation, pulmonary cancer, therapy.

\section{Introduction}

Lung tumour represents the neoplasm with the major incidence and mortality rates worldwide (1.35 million new cases annually and 1.18 million of deaths), with the highest frequency in Europe and the United States of America [1]. Among the different histological types, the most common are non-small cell lung cancer (NSCLC) and among these, adenocarcinoma is the most frequent $(30-40 \%)[2,3]$. The lung is a frequent site also for metastases, which occur in $30 \%$ of all cancers, especially from haematogenous spread. Patients with non-small cell lung cancer (NSCLC) have a median survival of 6 to 8 months, and 1-year survival rate for only 10-20\% [4]. The standard treatment for stages I, II and IIIa NSCLC is surgical resection, the unique approach with cure prospective and long-term survival [5]. Radiotherapy and chemotherapy are frequently used as adjuvant and/ or neoadjuvant therapies to surgery $[6,7,8]$. However, only about one third of the patients are eligible for surgery, and most of them have advanced disease at diagnosis [9]. Almost all patients have some comorbidities as poor pulmonary function, poor clinical conditions or advanced age and do not have sufficient clinical reserves to withstand a lobectomy or pneumonectomy [10]. Therefore, these patients are often treated with radiation therapy or palliative treatment $[11,12]$. Unfortunately, chemotherapy and external beam radiation therapy did not influence significantly the outcomes of patients with unresectable disease; in addition, greater efficacy in these therapies is often accompanied by significant toxicity, especially for patients with associated comorbidities. There is no gold standard treatment for inoperable patients both, thanks to their advanced disease and also owing to high surgical risk due to poor clinical conditions [13]. Therefore, the use of alternatives to conventional therapies such as percutaneous ethanol injection (PEI), thermal laser ablation, cryoablation, radiofrequency ablation (RFA) and microwave ablation (MWA), proves to be a good treatment option. Among these different therapies, the RFA has longer application and greater success, and was promptly introduced into clinical practice $[\mathbf{1 4 , 1 5 ]}$. The percutaneous RFA is increasing as a treatment for lung malignancies: the employment of RFA agitates the tissues ions surrounding the electrode, leading to a rotation at a high speed; consequently there is heat generation, thus responsible for tissue coagulation [16]. The latest advancements in minimally invasive

(C) 2012 Carrafiello et al; licensee Herbert Publications Ltd. This is an open access article distributed under the terms of Creative Commons Attribution License (http://creativecommons.org/licenses/by/3.0), This permits unrestricted use, distribution, and reproduction in any medium, provided the original work is properly cited. 
treatment for lung cancer are the MWA, which offer many of the RF benefits associated with theoretical advantages [17]. Despite the growing use of these techniques, it is still necessary to establish a clear and coherent criteria for patients selection to achieve a better definition of these therapies role $[\mathbf{1 8 , 1 9 , 2 0 , 2 1 ]}$. The aim of this study is to settle the most important clinical and radiological selection criteria for radiofrequency and microwave percutaneous ablation in patients with pulmonary tumours. With this intent, it is proposed a Literature Review and also the Personal Experience at Varese - Italy.

\section{Materials \& methods}

With the approval of Hospital's Ethics Committee, this retrospective study is based on the analysis of pulmonary thermal ablations performed in our service, based on medical data, on the angiographic room records, on clinical charts, on imaging and on data obtained at Surgery I and II, Thoracic Surgery and Oncology Departments, between May 2008 to May 2011, with special "focus" on clinical and radiological selection criteria involved in thermal ablation choice as a therapy. The criteria utilized were then compared with those employed in 24 studies chosen from Literature that fit the issue and described their patient selection criteria for lung tumours thermal ablation. The research was performed online on April 2011 using the words "lung and thermal ablation" on PubMed database.

\section{Results}

From May 2008 until May 2011, the thermal ablation was indicated as an alternative to the conventional treatment for 32 patients ( 20 males e 12 females), with medium age of 71 years old (range $46-82$ ). In one patient it wasn't possible to perform the procedure because he was under anticoagulation therapy (INR 2,2). There have been then performed 43 pulmonary thermal ablation sessions (14 RFA and 29 MWA sessions) in 33/34 lesions from 31/32 patients. Two of them had two lesions, treated in 2 different sessions (patients 17 and 19) (Tables 1-A, 1-B and 2).

All patients underwent laboratory exams, lung function tests (FEV1> $400 \mathrm{~mL}$ ) and baseline imaging (CT with iodine contrast). The reasons, risks and benefits of the procedure were discussed with all patients, who have signed the written informed consent. The blood count was regular in all patients $($ INR<1.5), except in the patient already mentioned (INR 2.2) and also in the patient referred to the oncologist for conventional treatment with chemotherapy. The other patients under anticoagulation and platelet antiaggregation therapy had suspended the treatment al least 7 days before the procedure, introducing fractionated heparin if necessary.

Biopsy was performed in all patients: 18 in our hospital and the remainder 14 had presented the outcomes from another hospitals.

The 34 lesions were histologically divided in 16 primaries (8 adenocarcinomas, 7 squamous cell carcinomas, 1 neuroendocrine carcinoma) e 18 metastasis (11 metastasis from colon carcinoma - 1 patient with 2 lesions, 2 metastasis from melanoma, 2 metastasis from cholangiocarcinoma in one patient, 1 metastasis from carcinoma from renal cells, 1 metastasis from breast carcinoma ad 1 metastasis from adrenal carcinoma) (Tables 1A , 1B and 2).

The clinical criteria that has leaded up the patients to thermal ablation therapy were: chronic obstructive pulmonary disease (COPD) in 9 cases, ischemic heart disease in 2 patients, tachyarrhythmia in 2 cases, chronic renal failure in 2 cases and carotid stenosis in 2 cases (1 patient bilaterally). One of the patients who underwent RFA had a pacemaker, with the lesion was apart from the device. The radiological signs were multiple pulmonary lesions $<4$ in number ( 15 cases), proximity over $1 \mathrm{~cm}$ from the heart and aortic trunk (1 case), and recent and stable extrapulmonary metastasis (2 cases, in liver and bone). The inoperability was a condition established for all patients, defined by anaesthesiologist and thoracic surgeon based on patients clinical condition, both by the extent and / or localization of the disease, or by the association between these factors. Previous failure of conventional therapies, such as previous ipsilateral atypical lung resection (3 cases), contralateral atypical lung resection (1 case), ipsilateral lung lobectomy (1 case), contralateral lobectomy (1 case), lobectomy of the lesions with greater diameter in the only case which the patient had 1 lesion in each lung, chemotherapy (1 case), radiotherapy ( 1 case) and 3 cases of MWA due to RFA recurrence (Tables 1A,1B and 2).

From November 2008, there has been the MWA advent; from the 31 patients that underwent thermal ablation therapy, 6 have undergone only to RFA, 20 only to MWA e 3 of them have undergone both ( 3 cases of RFA recurrence). From that moment on, it has been possible to perform thermal ablations in lesions with $<1 \mathrm{~cm}$ from vessels $>3 \mathrm{~mm}$ ( 9 cases), proximity of $>1 \mathrm{~cm}$ to heart and subclavians ( 1 case), and ablation of lesions with $>30 \mathrm{~mm}$ of diameter ( 8 cases) (Tables 1A,1B and 2). The results regarding the Literature Review are specified on Table 3.

Since this study involves only thermal ablations indications, data about efficacy, safety, follow-up and complications is fully tackled in another studies of the group both, for RFA $[18,22,23]$ and also for MWA [24].The recent MWA study has very promising results, in which MWA appears to be even better than RFA [24].

\section{Discussion}

Although an alternative approach to conventional treatments for NSCLC patients or carriers of lung metastases is essential, it is crucial to establish unequivocal selection criteria of patients suitable for percutaneous ablation [25].

Rose et al., [25] proposed guidelines for papers concerning lung tumors thermal ablation. Patient selection was one of the issues: it was emphasized that, because the ablation is not a gold standard treatment of lung cancer, the patient 
Table 1A. Patient Selection Criteria for Lung Ablation in Ospedale di Circolo di Varese.

\begin{tabular}{|c|c|c|c|c|c|c|c|c|c|c|c|}
\hline & & & & & & LINICAL & & & RADIOLOGICA & & \\
\hline 1 & M & $\begin{array}{l}\text { Metastasis from colorec- } \\
\text { tal cancer }\end{array}$ & $\mathrm{RF} / 1$ & & & & 51 & 10 & $\begin{array}{l}\text { Multiple le- } \\
\text { sions }<4\end{array}$ & & \\
\hline 3 & M & $\begin{array}{l}\text { Metastasis from clear } \\
\text { cell renal cell carcinoma }\end{array}$ & $\mathrm{RF} / 1$ & & $\begin{array}{l}\text { Pace- } \\
\text { maker }\end{array}$ & & 82 & 10 & $\begin{array}{l}\text { Multiple le- } \\
\text { sions }<4\end{array}$ & & \\
\hline 4 & $\mathrm{~F}$ & $\begin{array}{l}\text { Metastasis from esofa- } \\
\text { geous melanoma }\end{array}$ & $\mathrm{RF} / 1$ & & & & 64 & 25 & $\begin{array}{l}\text { Multiple le- } \\
\text { sions }<4\end{array}$ & & \\
\hline 5 & $\mathrm{~F}$ & Adenocarcinoma & $\begin{array}{c}\mathrm{RF} / 1 \\
\mathrm{MW} / 3\end{array}$ & & & & 71 & 46 & & $\begin{array}{l}\text { Adjacency } 5 \mathrm{~cm} \\
\text { to heart and } \\
\text { subclavians }\end{array}$ & $\begin{array}{c}\text { Previous } \\
\text { homolateral } \\
\text { lobectomy } \\
\text { Recurrence } \\
\text { post RFA }\end{array}$ \\
\hline 6 & $\mathrm{~F}$ & Squamous cell carcinoma & $\begin{array}{l}\text { Not } \\
\text { per- } \\
\text { formed }\end{array}$ & & $\begin{array}{l}\text { Ischemic } \\
\text { cardiomy- } \\
\text { opathy }\end{array}$ & COPD & 77 & 25 & & & $\begin{array}{l}\text { Atypical previ- } \\
\text { ous homolat- } \\
\text { eral resection }\end{array}$ \\
\hline 7 & M & Adenocarcinoma & $\begin{array}{c}\mathrm{RF} / 1 \\
\mathrm{MW} / 2\end{array}$ & $x$ & & COPD & 77 & 15 & & $\begin{array}{c}>1 \mathrm{~cm} \text { vessel }> \\
3 \mathrm{~mm}\end{array}$ & $\begin{array}{l}\text { Atypical previ- } \\
\text { ous homolat- } \\
\text { eral resection } \\
\text { Recurrence } \\
\text { post RFA }\end{array}$ \\
\hline 8 & M & $\begin{array}{l}\text { Metastasis from colorec- } \\
\text { tal cancer }\end{array}$ & $\mathrm{RF} / 2$ & $x$ & & COPD & 81 & $\begin{array}{l}15 \\
12\end{array}$ & $\begin{array}{l}\text { Multiple le- } \\
\text { sions }<4\end{array}$ & & \\
\hline 9 & $\mathrm{~F}$ & Adenocarcinoma & $\mathrm{RF} / 2$ & $x$ & & & 52 & 30 & $\begin{array}{l}\text { Bone metasta- } \\
\text { sis (recent) }\end{array}$ & & \\
\hline 13 & $\mathrm{~F}$ & Squamous cell carcinoma & $\mathrm{RF} / 1$ & $x$ & $\begin{array}{l}\text { Tachyar- } \\
\text { rhythmia }\end{array}$ & & 80 & 18 & & & \\
\hline 14 & M & Squamous cell carcinoma & $\mathrm{MW} / 1$ & $x$ & & COPD & 77 & 57 & & & \\
\hline 15 & M & $\begin{array}{l}\text { Neuroendocrine carci- } \\
\text { noma }\end{array}$ & $\mathrm{MW} / 1$ & & & & 69 & 11 & $\begin{array}{l}\text { Hepatic metas- } \\
\text { tasis (recente) }\end{array}$ & $\begin{array}{c}>1 \mathrm{~cm} \text { vessel }> \\
3 \mathrm{~mm}\end{array}$ & \\
\hline 16 & M & Squamous cell carcinoma & $\mathrm{MW} / 1$ & $x$ & & & 75 & 33 & $\begin{array}{l}\text { Multiple le- } \\
\text { sions }<4\end{array}$ & & $\begin{array}{l}\text { Previoush- } \\
\text { omolateral } \\
\text { lobectomy }\end{array}$ \\
\hline
\end{tabular}

RF: Radiofrequency. MW: Microwaves. COPD: chronic obstructive pulmonary disease. OCV: Ospedale di Circolo di Varese. 
Table 1B. Patient Selection Criteria for Lung Ablation in Ospedale di Circolo di Varese.

\begin{tabular}{|c|c|c|c|c|c|c|c|c|c|c|c|}
\hline & & & & & & INICAL & & & RADIOLOG & CAL & \\
\hline & & & & & $\begin{array}{l}\text { Associ- } \\
\text { ated } \\
\text { Comor- } \\
\text { bidities }\end{array}$ & $\begin{array}{l}\text { Poor } \\
\text { lung } \\
\text { function } \\
\text { (FEV1> } \\
400 \mathrm{~mL} \text { ) }\end{array}$ & Age & $\begin{array}{l}\text { Maxi- } \\
\text { mum } \\
\text { diam- } \\
\text { eter } \\
(\mathrm{mm})\end{array}$ & $\begin{array}{l}\text { Disease exten- } \\
\text { sion }\end{array}$ & $\begin{array}{l}\text { Adjacency to } \\
\text { large vessels (> } \\
3 \mathrm{~mm}) \text {, heart or } \\
\text { trachea }(\mathrm{cm})\end{array}$ & \\
\hline \multirow[t]{2}{*}{17} & \multirow[t]{2}{*}{$M$} & \multirow[t]{2}{*}{$\begin{array}{l}\text { Metastasis from } \\
\text { colorectal cancer }\end{array}$} & $\mathrm{MW} / 2$ & $x$ & & & 78 & 49 & $\begin{array}{l}\text { Multiple le- } \\
\text { sions }<4\end{array}$ & & \\
\hline & & & $\mathrm{MW} / 2$ & & & & & 16 & & & \\
\hline 18 & $M$ & Adenocarcinoma & $\mathrm{MW} / 1$ & $x$ & & COPD & 82 & 15 & & $\begin{array}{c}>1 \mathrm{~cm} \text { vessel }> \\
3 \mathrm{~mm}\end{array}$ & \\
\hline 19 & $\mathrm{~F}$ & $\begin{array}{l}\text { Metastasis from } \\
\text { colorectal cancer }\end{array}$ & $\mathrm{MW} / 1$ & $x$ & & & 46 & 15 & $\begin{array}{l}\text { Multiple le- } \\
\text { sions }<4\end{array}$ & & \\
\hline 20 & $M$ & $\begin{array}{l}\text { Metastasis from } \\
\text { melanoma right cheek } \\
\text { guancia } \mathrm{dx}\end{array}$ & $\mathrm{MW} / 1$ & $x$ & & & 71 & 23 & $\begin{array}{l}\text { Multiple le- } \\
\text { sions }<4\end{array}$ & & \\
\hline 21 & $M$ & Adenocarcinoma & $\mathrm{MW} / 1$ & $x$ & $\begin{array}{c}\text { CRF, } \\
\text { Bilateral } \\
\text { carotid } \\
\text { stenosis }\end{array}$ & & 74 & 25 & & $\begin{array}{c}>1 \mathrm{~cm} \text { vessel }> \\
3 \mathrm{~mm}\end{array}$ & \\
\hline 22 & $M$ & Adenocarcinoma & $\mathrm{MW} / 1$ & & & COPD & 68 & 40 & & & $\begin{array}{l}\text { Recurrence post } \\
\text { chemotherapy }\end{array}$ \\
\hline 23 & $M$ & Adenocarcinoma & $\mathrm{MW} / 1$ & $x$ & & COPD & 77 & 22 & & $\begin{array}{c}>1 \mathrm{~cm} \text { vessel }> \\
3 \mathrm{~mm}\end{array}$ & \\
\hline 24 & $M$ & $\begin{array}{l}\text { Metastasis from } \\
\text { colorectal cancer }\end{array}$ & $\mathrm{MW} / 1$ & $x$ & & COPD & 72 & 34 & $\begin{array}{l}\text { Multiple le- } \\
\text { sions }<4\end{array}$ & & \\
\hline 25 & $\mathrm{~F}$ & $\begin{array}{l}\text { Metastasis from adre- } \\
\text { nal carcinoma }\end{array}$ & $\mathrm{MW} / 1$ & & & & 57 & 8 & & $\begin{array}{c}>1 \mathrm{~cm} \text { vessel }> \\
3 \mathrm{~mm}\end{array}$ & \\
\hline 26 & $M$ & $\begin{array}{l}\text { Metastasis from } \\
\text { colorectal cancer }\end{array}$ & $\mathrm{MW} / 1$ & $x$ & & & 70 & 28 & & $\begin{array}{c}>1 \mathrm{~cm} \text { vessel }> \\
3 \mathrm{~mm}\end{array}$ & \\
\hline 27 & $\mathrm{~F}$ & $\begin{array}{l}\text { Carcinoma squamocel- } \\
\text { lulare }\end{array}$ & $\mathrm{MW} / 2$ & $x$ & $\begin{array}{l}\text { Carotid } \\
\text { stenosis }\end{array}$ & & 69 & 96 & $\begin{array}{l}\text { Multiple le- } \\
\text { sions }<4\end{array}$ & & \\
\hline 28 & $\mathrm{~F}$ & $\begin{array}{l}\text { Metastasi colangiocar- } \\
\text { cinoma }\end{array}$ & $\mathrm{MW} / 1$ & & & & 77 & 23 & $\begin{array}{l}\text { Multiple le- } \\
\text { sions }<4\end{array}$ & & $\begin{array}{l}\text { Previous } \\
\text { homolateral }\end{array}$ \\
\hline 29 & $F$ & $\begin{array}{l}\text { Squamous cell carci- } \\
\text { noma }\end{array}$ & $\mathrm{MW} / 1$ & $x$ & & & 66 & $\underline{100}$ & & $\begin{array}{l}\text { Encephalic metas- } \\
\text { tasis (recent) }\end{array}$ & \\
\hline 30 & $M$ & $\begin{array}{l}\text { Metastasis from } \\
\text { colorectal cancer }\end{array}$ & $\mathrm{MW} / 1$ & & & & 71 & 20 & $\begin{array}{l}\text { Multiple le- } \\
\text { sions }<4\end{array}$ & & \\
\hline 31 & $\mathrm{~F}$ & $\begin{array}{l}\text { Metastasis from } \\
\text { colorectal cancer }\end{array}$ & $\mathrm{MW} / 1$ & & & & 67 & 14 & & $\begin{array}{c}>1 \mathrm{~cm} \text { vessel }> \\
3 \mathrm{~mm}\end{array}$ & $\begin{array}{l}\text { Atypical previ- } \\
\text { ous homolateral } \\
\text { resection }\end{array}$ \\
\hline 32 & $M$ & Adenocarcinoma & $\mathrm{MW} / 1$ & & $\begin{array}{l}\text { CRF, } \\
\text { Tachyar- } \\
\text { rhythmia }\end{array}$ & & 77 & 15 & & & $\begin{array}{l}\text { Atypical previ- } \\
\text { ous controlat- } \\
\text { eral resection- } \\
\text { Recurrence post } \\
\text { radiotherapy }\end{array}$ \\
\hline
\end{tabular}

RF: Radiofrequency. MW: Microwaves. CRF: chronic renal failure. COPD: chronic obstructive pulmonary disease. OCV: Ospedale di Circolo di Varese. 
Table 2. Patients and lesions characteristics and selection criteria for percutaneous lung thermal ablation $(n=32)$

\begin{tabular}{|c|c|c|}
\hline \multirow{2}{*}{\multicolumn{2}{|c|}{$\begin{array}{l}\text { Males/Females } \\
\text { Age }\end{array}$}} & $20 / 12$ \\
\hline & & \\
\hline \multicolumn{2}{|l|}{ Media } & 71 \\
\hline \multicolumn{2}{|l|}{ Range } & $46-82$ \\
\hline \multicolumn{3}{|c|}{ Lesions Histology $(n=34)$} \\
\hline \multicolumn{2}{|c|}{ Primaries } & 16 \\
\hline & Adenocarcinoma & 8 \\
\hline & Squamous cell carcinoma & 7 \\
\hline & Neuroendocrine & 1 \\
\hline \multicolumn{2}{|c|}{ Metastasis } & 18 \\
\hline & Colon & 11 \\
\hline & Melanoma & 2 \\
\hline & Cholangiocarcinoma & 2 \\
\hline & Breast & 1 \\
\hline & Adrenal & 1 \\
\hline & Kidney & 1 \\
\hline \multicolumn{3}{|c|}{ Lesions Diameter $(\mathrm{mm})$} \\
\hline \multicolumn{2}{|l|}{ Media } & 28.3 \\
\hline \multicolumn{2}{|l|}{ Range } & $8-100$ \\
\hline \multicolumn{3}{|c|}{ Selection Criteria for Ablation } \\
\hline \multicolumn{3}{|l|}{ Clinical } \\
\hline & COPD & 9 \\
\hline & Ischemic cardiomyopathy & 1 \\
\hline & Tachyarrhythmia & 2 \\
\hline & Pacemaker & 1 \\
\hline & CRF & 2 \\
\hline & Carotid stenosis & 2 \\
\hline \multicolumn{3}{|c|}{ Radiological } \\
\hline \multicolumn{3}{|c|}{ RFA o MWA } \\
\hline & Multiple lesions $<4$ & 15 \\
\hline \multicolumn{3}{|c|}{ MWA } \\
\hline & Diameter $>3 \mathrm{~cm}$ & 8 \\
\hline & Vessels adjacency $>3 \mathrm{~mm}$ & 9 \\
\hline & Recurrence post RFA & 3 \\
\hline \multicolumn{2}{|c|}{ Failure of conventional therapies } & 8 \\
\hline & Chemotherapy & 1 \\
\hline & Surgical resection & 6 \\
\hline & Radiotherapy and surgical resection & 1 \\
\hline
\end{tabular}

CRF: chronic renal failure. COPD: chronic obstructive pulmonary disease.

selection criteria should always be clearly described.

\section{Pre treatment recommendation}

The biopsy should always be performed to confirm the diagnosis of malignancy [26]. Biopsy was performed in all patients: 18 have been performed in our hospital and the other 14 presented the outcomes from another hospital. From the 24 studies analyzed, 12 [21,27-37] emphasized the biopsy significance, and reported the possibility to perform it at the same session of the procedure [29]. Three studies revealed to make use of clinical evidence as disease confirmation in
Table 3. Literature studies and their patient selection criteria for percutaneous lung thermal ablation

Criteria from Literature

Pretreatment reccomendation

Biopsy

Coagulation disorders

Specialist responsable of the choice

Clinical criteria

$$
\begin{aligned}
& \text { Poor lung function } \\
& \text { Comorbidity } \\
& \text { Advanced age }
\end{aligned}
$$

Imaging criteria

Limit value for lesion's diameter
Extension of local disease
Maximum Diameter
Localization (close to major vessels, heart, trachea,
hilum)

case of metastatic lesions histologically known or recurrences, without performing biopsy $[29,32,36]$. Coagulation disorders may exclude patients from selection for thermal ablation therapy [38-40]. One of our patients could not undergo the procedure as long as he didn't discontinue the anticoagulation therapy 7 days before the procedure (INR $>2.2$ ).

Of the 24 studies reported, only $9[13,21,29,32,34,37,41-43]$ have reported the concern with haematological disorders, and among these, $7[13,21,29,32,34,42,43]$ have specified their limit of INR and / or platelet count as a factor of exclusion. In our Centre, a INR $>1.5$ and platelet count $<35,000 / \mathrm{mL}$ had excluded patients as candidates for thermal ablation. A lack of attention to haematological index can more likely lead to peri-lesional hemorrhage and other complications that could be lethal [18].

\section{Clinical criteria}

All patients who undergo ablative therapies should not be candidable for conventional treatment or should have not answered to these treatments $[\mathbf{3 9}, \mathbf{4 4 , 4 8}]$. This decision is usually undertaken by a multidisciplinary team, in our case, the reference clinician (oncologist or pneumologist), the thoracic surgeon, the interventional radiologist and the anaesthesiologist. Of the 24 studies analyzed, this data is found only in 12 studies [13,30,34-37,43,46-49]; a group formed by interventional radiologist, thoracic surgeon and anaesthesiologist is present in another study [37], the other 
teams are made up of only pneumologist (1 study) [48], anaesthesiologist and surgeon (1 study) [34], only thoracic surgeon (5 studies) [36,43,47-49], surgeon and oncologist (1 study) [13], thoracic surgeon and interventional radiologist (2 studies) $[37,46]$ and pneumologist, oncologist, radiotherapist and thoracic surgeon (1 study) [30].

Among the characteristics that define inoperability, poor lung function is considered in 19 studies $[13,21,30,34,36,42,43,46,48-52] ; 8$ studies reported also the FEV1 value $[27,30,36,53,48,49,51,52]$, and 4 have also reported the DLCO (diffusion capacity of CO2) $[36,48,49]$. Of our 32 patients, 9 were had COPD and all had a FEV $1>400 \mathrm{ml}$. In Literature and in our group of patients, poor lung function has always been a factor associated with clinical comorbidities or other radiological criteria, and has never been a singular factor for the thermal ablation decision.

The clinical comorbidities detected in our study were: cardiomyopathies (ischemic and tachyarrhythmias) in 3 cases; carotid stenosis in 2 cases; chronic renal failure in 2 cases. All of these factors have contributed to the decision of inoperability. In one pacemaker carrier patient despite undergoing RFA instead of MWA (the latter is saffer for these patients due to the absence of electric current involving the patient), the advice was distant from the injury and did not cause any complication. Of the 24 studies, $17[13,21,29,30,34-37,41,46-49,51,52,54]$ cited the co-morbidities as inoperability criteria; hepatic cirrhosis [46], chronic renal failure [46], hemodynamic disorders [30], multiple sclerosis [30], aortic aneurysm [30], congestive heart failure [36], low "performance status" [43,49,51] (reported in three different scales, Zubrod, Charlson Comorbidity Index, and ECOG), stable angina [49], to valvulopathies [36] and the high cardiac risk [52] were the co-morbidities reported by the studies analyzed. It is paramount that the risk of decease of from co-morbidities outweighs the risk of decease from cancer; otherwise the patient is automatically not candidable even for thermo ablations [55].

From the 24 papers, only $4[13,28,29,52]$ mentioned advanced age as a factor of inoperability; in our study, age was considered as an indirect factor in the inoperability definition, once our patients had invariably other associated comorbidities and radiological criteria for the thermal ablation election. In the follow-up of another studies of our Centre, patients who deceased had the progression of neoplastic disease as the cause of death, and not their poor clinical conditions, confirming this study decision to refer these patients to thermo ablative treatment [18]. Of the 24 studies analyzed, $20[13,21,27-29,31,33-37,42,43,46,48,50-54]$ reported patients with lung metastases, and most of them, as in our study, had origin from the colon: 17 of our patients had lung metastases (11 lesions originated from colon cancer). The employment of thermal ablation for lung metastasis is widespread and shows excellent results $[13,29]$.

None of our patients underwent the thermal ablation procedure for surgical refuse; this "inoperability" reason was present in $18[21,27,29,30,33,34,36,37,41-43,46-52]$ of the 24 reported studies.

\section{Radiological criteria}

It is possible to define as important radiological criteria for patient inclusion to percutaneous thermal ablation for lung tumors with curative intent: lesion diameter, disease extension (lesions number and extrapulmonary lesions) and the adjacency to major vessels $(>3 \mathrm{~mm})$, heart or trachea $[\mathbf{9}, \mathbf{1 8}, \mathbf{2 7}-\mathbf{3 0}, \mathbf{5 6}, \mathbf{5 7 - 6 2}]$. For the latter criteria, the ablative technology typology influences a lot; despite the inclusion criteria for RFA and MWA are most likely the same, MWA amplifies RFA radiological application $[18,19]$.

The treatment of lung lesions with MWA has modified the percutaneous approach of this pathology in our Centre from 2008 on. The microwave technique is a relative new ablative treatment applicable to different neoplasm typologies, able to offer all radiofrequency benefits, moreover introducing other substantial advantages $[\mathbf{1 8 , 1 9 ]}$. Several are the advantages offered by this technology: major volume of cellular necrosis, reduction on time of procedure, major temperatures achieved to target lesion, possibility to use multiple antenna simultaneously, efficacy in lesions with cystic components and/or lesions in adjacency to vascular structures with diameter $>3 \mathrm{~mm}$ and less intraprocedural pain $[18,19,21,63-69]$. In RFA the tissue overheating direct activity is limited to a zone surrounding the active electrode for only a few millimetres, while the temperature rises in the remaining target lesion takes place only thought simple terminal conduction $[18,19,68,69]$. MWA instead, inducing water particles to flip back and forward at a speed of 2-5 billion times per second according to the waves frequency themselves, allow to obtain as better convective profile, determining a more homogeneous coagulative necrosis at the target lesion $[18,19,63,64,69]$. The microwave ablative system allows the simultaneous positioning of multiple antenna each one connected to its own generator, in order to obtain a necrosis diameter of $6 \mathrm{~cm}$, overcoming the dimensional RFA limits $[18,19]$. Comparing the data found in this study with the data available in Literature its possible to apprehend that the medium necrosis diameter obtained with MWA is larger (medium diameter $\pm 3.5 \mathrm{~cm}$ ) than the one achieved with RFA (medium diameter $1.7 \mathrm{~cm} \pm 1.0 \mathrm{~cm}$ ) [18].

While in our study we have compared the selection criteria for RFA and MWA, among the 24 articles analyzed in Literature, just one of them reports selection criteria for MWA [21]. Whereas the latter is a relatively recent therapy, there are still not many clinical studies available in Literature that regarding it, especially there are not many studies reporting the inclusion and exclusion criteria for patient selection.

In our study, the lesions diameter range was 8 to $100 \mathrm{~mm}$ (media $28.3 \mathrm{~mm}$ ). The lesions $>30 \mathrm{~mm}$ were all treated with RFA. From the 24 studies analyzed, only 11 established a

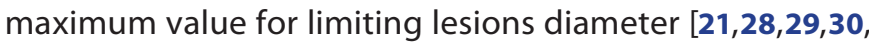


$34,35,42,43,47,49,52]$, which varied from $\leq 30$ to $\leq 6 \mathrm{~mm}$. The single study that reported the MWA experience had $\leq 50$ $\mathrm{mm}$ as a limit for lesions diameter [21]. There is not a consent regarding the superior lesion maximum diameter: it is known that the percentage of compete ablation for RFA for tumours larger than $3 \mathrm{~cm}$ in diameter has revelled to be inappreciable in several studies [27-30,59-62], but in a multi centre study, a maximum diameter of $5 \mathrm{~cm}$ has been defined as limiting for RFA, and that it is possible to employ it in largest lesions with a purpose of reducing symptomatology $[26,58,70,71]$. Another Centres had established 3,5cm, another even $7 \mathrm{~cm}$ as maximum diameter for solitary tumours $[39,72]$. It has been recently demonstrated that MWA permits instead an effective ablation also for lesions larger than $4 \mathrm{~cm}$ in diameter [18].

The disease extension has been contended in 19 $[13,21,27,30,32,34,35,37,41-43,46-50,54]$ of the 24 studies involved, attesting its importance. In our group of 32 patients, having multiple lesions $<4$ was considered as an inclusion criterion to the treatment ( 15 patients). Patients with $>4$ lesions per hemithorax have been considered not candidable for surgery. From the 15 multiple lesions <4, only in 2 cases the multiple lesions were related to primitive lung tumours, the remaining were secondary lesions, with the origin tumours controlled and with the lung the only organ restraining metastatic lesions. It is important to stress that thermal ablation in these cases should be reserved for patients with a elevated risk if submitted to surgical resection [45]. In our group, 1 patient had bilateral metastasis that were treated with MWA in a interval time of 2 months to avoid the complications that could threat the patients life, as haemorrhage or bilateral pneumothorax. Nonetheless, when the patient has a preview surgical resection in same lung of the target lesion without any complications, the pneumothorax risk is lower and there have been reported treatments in both lungs in the same session [56]. This bilateral treatment is related to a minute percentage of cases reported and is strictly designate to patients completely free of complications detected on preoperative CT [56]. None of the 24 studies analyzed reports bilaterality cases.

Extra pulmonary metastases were an exclusion criterion in our study, such as in $6[13,21,35,37,43,50]$ of the 19 studies that approach the disease extension for patient selection. Only 3 of our 32 patients had extrapulmonary metastasis and in this cases. Thermal ablation has been performed with citoreduction purpose and not with a curative aim. Five studies $[34,41,42,49,52]$ had completely excluded the patients with extrapulmonary metastasis; one of these studies excludes the patients with advanced disease [52]. On the other hand, it has been demonstrated by several Authors that thermal ablation have an important role in palliation (citoriduction) also for symptoms in advanced stages of disease $[9,16,39]$. Indications for palliative ablation include dyspnea, cough, hemoptysis or pain related to disease progression [73]. Remarkable reduction of pain, cough, hemoptysis and dyspnea is reported by several

\section{Authors $[27,41,74,75]$.}

Regarding the tumour localization, 31 of our patients had lesions in the external 2/3 of the lung; only one of them had one lesion closer $<5 \mathrm{~cm}$ from supra-aortic trunk; after a first RFA session, there have been performed other 2 MWA sessions, more appropriate for lesions in adjacency to vessels with diameter $>3 \mathrm{~mm}$. There were not complications. Moreover it is important to consider the experience of Iguchi et al., [62] that had adequately performed RFA in 42 lung tumors located at less than $10 \mathrm{~mm}$ of aorta or heart, without any complication related to the adjacency to those structures. None of or patients had thought lesions in adjacency to heart or hilus. Ten $[13,21,29,34,36,37,47,48,53,54]$ of our 24 studies analyzed had as exclusion criteria lesions in adjacency to heart, hilum or large vessels, while $4[29,32,36,47]$ of these studies suggests a minimum safety distant. Instead, two $[13,34]$ studies exclude only the lesions with invasion of these structures. It is known that a distance closer to $1 \mathrm{~cm}$ from hilum can lead to damage to surrounding organs, hence should be avoided [76].

In our study, 9 of the 32 patients had lesions close to vessels $>3 \mathrm{~mm}$; therefore it has been proposed the MWA, such as to the other 8 patients with lesions with diameter $>$ di $30 \mathrm{~mm}$. Three of the 6 patients who underwented RFA have had recurrence, and there have been submitted also to MWA.

Conventional therapies failure is another indication of thermoablation $[\mathbf{1 3}, \mathbf{5 9}, \mathbf{7 3}]$. In our group of patients, 8 had not answered to chemotherapy (1 case), surgical resections ( 6 cases) and the association between surgical resection and radiotherapy (1 case). Among the patients submitted to surgical resection, 5 have underwent to resection or lobectomies homolateral to the target lesion for the thermal ablation and 2 of them to controlateral resections, included the case in association with radiotherapy. None of our patients had undergone pneumectomy. Thermal ablations are particularly beneficial to patients that presented an isolated recurrence after pulmonary resection [47].The benefit is considerable also in advanced stage, with satisfactory previous response to radiation and chemotherapy, but with a solitary and peripheral [47]. The patients previously submitted to pneumectomy must be considered at high risk for contro-lateral pulmonary RFA ablation: the procedure should be performed only if there is the availability of thoracic surgeons and anaesthesiologists, such as the accessibility to the intensive care unite [77]. Despite this consideration, one from the $17[21,27-29,31-33,36,41-43,46-$ $\mathbf{4 8 , 5 2 , 5 4 ]}$ studies that approaches the failure of conventional therapies as an inclusion criterion, the pneumectomy is an inclusion criterion, and only in one [13] study pneumectomy with remaining lesion is an exclusion criterion. However, another study [29] excludes all patients that had undergone a surgery at the same lung.

One study [31] uses as inclusion criteria only serious side effects from chemotherapy and radiotherapy, and not necessarily its failure.

In Literature review, it has been possible to notice that, 
differently from the uniformity suggested from Rose et al., [25] for the transcription of patient selection data in all papers written about thermal ablation, a clear exposition of patient selection criteria is not still exposed from all Centres.

Among the studies that report the patient selection criteria with primitive and secondary neoplasms it is possible to find a nexus among them and also with the reported data for patient selection in our Hospital. It is then possibile to conclude that the main criteria for lung tumors thermalablation is based on inoperability, and can be divided with a didactic purpose in clinical and radiological $[13,21,27-31,33-35,39,41,42,45$ 47,50,51,53,54].

A clear exposition of selection criteria is still not a routine for Authors. For that reason is not momentarily possible to establish unambiguous thermo ablative therapies indications criteria. Whereas, it is necessary a randomized controlled study with a control group submitted to conventional therapies to define with precision patients candidable to thermal ablative therapies.

\section{Competing interests}

The authors declare no conflicts of interest.

Publication history

Received: 19-June-2012 Revised: 28-June-2012

Accepted: 10-Aug-2012 Published: 21-Aug-2012

\section{References}

1. Parkin DM, Bray F, Ferlay J, et al., Global cancer statistics, 2002. CA Cancer J Clin 2005; 55;74-108. | Article

2. Associazione Italiana dei Registri Tumorali. Tumori in Italia - Rapporto 2006. Associazione Italiana Registri Tumorali 2006. Visited on May 2011. I Link

3. Minna JD. (2005) Neoplasms of the lung. In: Kasper DL, Eugene Braunwald E, Stephen Hauser S, et al., Harrison's principals of internal medicine. McGraw-Hill. New York, pp506-516.

4. Ferlay J, Autier P, Boniol M, Heanue M, Colombet M, Boyle P: Estimates of the cancer incidence and mortality in Europe in 2006. Ann Oncol 2007; 18;(3.);581-92. I Article I PubMed

5. U.S. Cancer Statistics Working Group. United States Cancer Statistics: 1999-2007 Incidence and Mortality Web-based Report. Atlanta (GA): Department of Health and Human Services, Centers for Disease Control and Prevention, and National Cancer Institute; 2010. | Link

6. Joe BPJ. (2003) Polmone. In: Sabiston DCJ. Trattatto di Chirurgia. Le basi biologiche della moderna pratica chirurgia. Antonio Delfino Editore. Roma, pp 1213-28.

7. Shugarman LR, Mack K, Sorbero ME, Tian H, Jain AK, Ashwood JS, et al.: Race and sex differences in the receipt of timely and appropriate lung cancer treatment. Med Care 2009; 47;(7.);774-81. | Article | PubMed

8. Slowik-Gabryelska A, Szczepanik A, Kalicka A: [The quality of life after chemotherapy in advanced non-small cell lung cancer patients]. Pol Merkur Lekarski 1999; 6;(31.);18-22. | PubMed

9. Casal RF, Tam AL, Eapen GA: Radiofrequency ablation of lung tumors. Clin Chest Med 2010; 31;(1.);151-63, Table of Contents. | Article | PubMed

10. Silvestri GA, Sherman C, Williams T, Leong SS, Flume P, Turrisi A: Caring for the dying patient with lung cancer. Chest 2002; 122;(3.);1028-36. | Article | PubMed

11. Fry WA, Phillips JL, Menck HR: Ten-year survey of lung cancer treatment and survival in hospitals in the United States: a national cancer data base report. Cancer 1999; 86;(9.);1867-76. | Article | PubMed

12. Marino P, Preatoni A, Cantoni A: Randomized trials of radiotherapy alone versus combined chemotherapy and radiotherapy in stages IIIa and IIIb nonsmall cell lung cancer. A meta-analysis. Cancer 1995; 76;(4.);593-601. | Article | PubMed

13. Thanos L, Mylona S, Ptohis N, Tsiouris S, Sotiropoulou E, Pomoni A, et al.: Percutaneous radiofrequency thermal ablation in the management of lung tumors: presentation of clinical experience on a series of 35 patients. Diagn Interv Radiol 2009; 15;(4.);290-6. | PubMed

14. Dupuy DE, Mayo-Smith WW, Abbott GF, DiPetrillo T: Clinical applications of radio-frequency tumor ablation in the thorax. Radiographics 2002; 22 Spec No;(S259-69. | Article | PubMed

15. Dupuy DE, Goldberg SN: Image-guided radiofrequency tumor ablation: challenges and opportunities--part II. J Vasc Interv Radiol 2001; 12;(10.);1135-48. | Article I PubMed

16. Matsuoka T, Okuma T: CT-guided radiofrequency ablation for lung cancer. Int J Clin Oncol 2007; 12;(2.);71-8. I Article | PubMed

17. Wasser EJ, Dupuy DE: Microwave ablation in the treatment of primary lung tumors. Semin Respir Crit Care Med 2008; 29;(4.);384-94. | Article | PubMed

18. Carrafiello G, Lagana D, Mangini M, Fontana F, Dionigi G, Boni L, et al.: Microwave tumors ablation: principles, clinical applications and review of preliminary experiences. Int J Surg 2008; 6 Suppl 1;(S65-9. | Article | PubMed

19. Simon CJ, Dupuy DE, Mayo-Smith WW: Microwave ablation: principles and applications. Radiographics 2005; 25 Suppl 1;(S69-83. | Article | PubMed

20. Dupuy DE, Zagoria RJ, Akerley W, Mayo-Smith WW, Kavanagh PV, Safran H: Percutaneous radiofrequency ablation of malignancies in the lung. $A J R$ Am J Roentgenol 2000; 174;(1.);57-9. | Article | PubMed

21. Wolf FJ, Grand DJ, Machan JT, Dipetrillo TA, Mayo-Smith WW, Dupuy DE: Microwave ablation of lung malignancies: effectiveness, $C T$ findings, and safety in 50 patients. Radiology 2008; 247;(3.);871-9. | Article | PubMed

22. Carrafiello G, Mangini M, Fontana F, Lagana D, Cotta E, Di Massa A, et al.: Radiofrequency ablation for single lung tumours not suitable for surgery: seven years' experience. Radiol Med 2012. | Article | PubMed

23. Carrafiello G, Mangini M, Fontana F, Di Massa A, lerardi AM, Cotta E, et al.: Complications of microwave and radiofrequency lung ablation: personal experience and review of the literature. Radiol Med 2012; 117;(2.);20113. | Article | PubMed

24. Carrafiello G, Mangini M, Fontana F, lerardi AM, De Marchi G, et al., Microwave ablation of lung tumours: single center preliminary experience. Radiol Med 2012 [in press].

25. Rose SC, Dupuy DE, Gervais DA, Millward SF, Brown DB, Cardella JF, et al.: Research reporting standards for percutaneous thermal ablation of lung neoplasms. J Vasc Interv Radiol 2009; 20;(7 Suppl.);S474-85. | Article | PubMed

26. Fernando HC: Radiofrequency ablation to treat non-small cell lung cancer and pulmonary metastases. Ann Thorac Surg 2008; 85;(2.);S780-4. | Article | PubMed

27. Lee JM, Jin GY, Goldberg SN, Lee YC, Chung GH, Han YM, et al.: Percutaneous radiofrequency ablation for inoperable non-small cell lung cancer and metastases: preliminary report. Radiology 2004; 230;(1.);125-34. | Article | PubMed

28. Akeboshi M, Yamakado K, Nakatsuka A, Hataji O, Taguchi O, Takao M, et al.: Percutaneous radiofrequency ablation of lung neoplasms: initial therapeutic response. J Vasc Interv Radiol 2004; 15;(5.);463-70. I Article I PubMed

29. Ambrogi MC, Fontanini G, Cioni R, Faviana P, Fanucchi O, Mussi A: Biologic effects of radiofrequency thermal ablation on non-small cell lung cancer: results of a pilot study. J Thorac Cardiovasc Surg 2006; 131;(5.);1002-6. | Article I PubMed

30. Grieco CA, Simon CJ, Mayo-Smith WW, DiPetrillo TA, Ready NE, Dupuy $\mathrm{DE}$ : Percutaneous image-guided thermal ablation and radiation therapy: 
outcomes of combined treatment for $\mathbf{4 1}$ patients with inoperable stage I/II non-small-cell lung cancer. J Vasc Interv Radiol 2006; 17;(7.);111724. | PubMed

31. He W, Hu XD, Wu DF, Guo L, Zhang LZ, Xiang DY, et al.: Ultrasonographyguided percutaneous microwave ablation of peripheral lung cancer. Clin Imaging 2006; 30;(4.);234-41. | Article | PubMed

32. Suh RD, Wallace AB, Sheehan RE, Heinze SB, Goldin JG: Unresectable pulmonary malignancies: CT-guided percutaneous radiofrequency ablation--preliminary results. Radiology 2003; 229;(3.);821-9. | Article I PubMed

33. Kishi K, Nakamura H, Kobayashi K, Hashimoto T, Hatao H, Oh-ishi S, et al.: Percutaneous CT-guided radiofrequency ablation of pulmonary malignant tumors: preliminary report. Intern Med 2006; 45;(2.);65-72. | Article | PubMed

34. Rossi S, Dore R, Cascina A, Vespro V, Garbagnati F, Rosa L, et al.: Percutaneous computed tomography-guided radiofrequency thermal ablation of small unresectable lung tumours. Eur Respir J 2006; 27;(3.);556-63. I Article | PubMed

35. Cariati M, Giordano G, Midulla M, Calati AM, Sacrini A, Raveglia F, et al.: Radiofrequency ablation of pulmonary lesions. Radiol Med 2007; 112;(2.);149-56. | Article | PubMed

36. Pennathur A, Abbas G, Gooding WE, Schuchert MJ, Gilbert S, Christie $N A$, et al.: Image-guided radiofrequency ablation of lung neoplasm in $\mathbf{1 0 0}$ consecutive patients by a thoracic surgical service. Ann Thorac Surg 2009; 88;(5.);1601-6; discussion 7-8. | Article | PubMed Abstract | PubMed Full Text

37. Suzuki T, Yamagami T, Tanaka O, Yoshimatsu R, Miura H, Nishimura T: Percutaneous radiofrequency ablation for lung tumors beneath the rib under CT fluoroscopic guidance with gantry tilt. Acta Radiol 2010; 51;(4.);389-95. | Article | PubMed

38. Roy AM, Bent C, Fotheringham T: Radiofrequency ablation of lung lesions: practical applications and tips. Curr Probl Diagn Radiol 2009; 38;(1.);44-52. | Article | PubMed

39. VogI TJ, Naguib NN, Lehnert T, Nour-Eldin NE: Radiofrequency, microwave and laser ablation of pulmonary neoplasms: clinical studies and technical considerations--review article. Eur J Radiol 2011; 77;(2.);34657. | Article | PubMed

40. Steinke K: Radiofrequency ablation of pulmonary tumours: current status. Cancer Imaging 2008; 8;(27-35. | Article | PubMed Abstract | PubMed Full Text

41. Belfiore G, Moggio G, Tedeschi E, Greco M, Cioffi R, Cincotti F, et al.: CTguided radiofrequency ablation: a potential complementary therapy for patients with unresectable primary lung cancer--a preliminary report of 33 patients. AJR Am J Roentgenol 2004; 183;(4.);1003-11. | Article | PubMed

42. Yan TD, King J, Sjarif A, Glenn D, Steinke K, Morris DL: Learning curve for percutaneous radiofrequency ablation of pulmonary metastases from colorectal carcinoma: a prospective study of 70 consecutive cases. Ann Surg Oncol 2006; 13;(12.);1588-95. | Article | PubMed

43. Soga N, Yamakado K, Gohara H, Takaki H, Hiraki T, Yamada T, et al.: Percutaneous radiofrequency ablation for unresectable pulmonary metastases from renal cell carcinoma. BJU Int 2009; 104;(6.);790-4. | Article I PubMed

44. Abbas G, Pennathur A, Landreneau RJ, Luketich JD: Radiofrequency and microwave ablation of lung tumors. J Surg Oncol 2009; 100;(8.);645-50. | Article | PubMed

45. Fernando HC, Hoyos AD, Litle V, Belani CP, Luketich JD: Radiofrequency ablation: identification of the ideal patient. Clin Lung Cancer 2004; 6;(3.);149-53. | Article | PubMed

46. Yasui K, Kanazawa S, Sano Y, Fujiwara T, Kagawa S, Mimura H, et al.: Thoracic tumors treated with CT-guided radiofrequency ablation: initial experience. Radiology 2004; 231;(3.);850-7. | Article | PubMed

47. Fernando HC, De Hoyos A, Landreneau RJ, Gilbert S, Gooding WE, Buenaventura $\mathrm{PO}$, et al.: Radiofrequency ablation for the treatment of non-small cell lung cancer in marginal surgical candidates. J Thorac
Cardiovasc Surg 2005; 129;(3.);639-44. | Article | PubMed

48. Pennathur A, Abbas G, Qureshi I, Schuchert MJ, Wang Y, Gilbert S, et al.: Radiofrequency ablation for the treatment of pulmonary metastases. Ann Thorac Surg 2009; 87;(4.);1030-6; discussion 6-9. | Article | PubMed Abstract | PubMed Full Text

49. Lanuti M, Sharma A, Digumarthy SR, Wright CD, Donahue DM, Wain JC, et al.: Radiofrequency ablation for treatment of medically inoperable stage I non-small cell lung cancer. J Thorac Cardiovasc Surg 2009; 137;(1.);160-6. | Article | PubMed

50. Yan TD, King J, Ebrahimi A, Sjarif A, Glenn D, Steinke K, et al.: Hepatectomy and lung radiofrequency ablation for hepatic and subsequent pulmonary metastases from colorectal carcinoma. J Surg Oncol 2007; 96;(5.);367-73. | Article | PubMed

51. Hiraki $T$, Gobara $H$, lishi $T$, Sano $Y$, Iguchi $T$, Fujiwara $H$, et al.: Percutaneous radiofrequency ablation for clinical stage I non-small cell lung cancer: results in $\mathbf{2 0}$ nonsurgical candidates. J Thorac Cardiovasc Surg 2007; 134;(5.);1306-12. | Article | PubMed

52. Huang L, Han Y, Zhao J, Wang X, Cheng $Q$, Li X, et al.: Is radiofrequency thermal ablation a safe and effective procedure in the treatment of pulmonary malignancies? Eur J Cardiothorac Surg 2011; 39;(3.);348-51. | Article | PubMed

53. Suh RD, Wallace AB, Sheehan RE, Heinze SB, Goldin JG: Unresectable pulmonary malignancies: CT-guided percutaneous radiofrequency ablation--preliminary results. Radiology 2003; 229;(3.);821-9. | Article I PubMed

54. King J, Glenn D, Clark W, Zhao J, Steinke K, Clingan P, et al.: Percutaneous radiofrequency ablation of pulmonary metastases in patients with colorectal cancer. Br J Surg 2004; 91;(2.);217-23. | Article | PubMed

55. McTaggart RA, Dupuy DE: Thermal Ablation of Lung Tumors. Techniques in Vascular and Interventional Radiology 2007; 10;(2.);102-13. | Article

56. de Baere T: Lung tumor radiofrequency ablation: where do we stand? Cardiovasc Intervent Radiol 2011; 34;(2.);241-51. | Article | PubMed

57. Pua BB, Solomon SB: Radiofrequency ablation of primary and metastatic lung cancers. Semin UItrasound CT MR 2009; 30;(2.);113-24. | PubMed

58. Herrera LJ, Fernando HC, Perry Y, Gooding WE, Buenaventura PO, Christie NA, et al.: Radiofrequency ablation of pulmonary malignant tumors in nonsurgical candidates. The Journal of Thoracic and Cardiovascular Surgery 2003; 125;(4.);929-37. | Article

59. Simon CJ, Dupuy DE: Current role of image-guided ablative therapies in lung cancer. Expert Rev Anticancer Ther 2005; 5;(4.);657-66. | Article | PubMed

60. Ambrogi MC, Dini P, Melfi F, Mussi A: Radiofrequency ablation of inoperable non-small cell lung cancer. J Thorac Oncol 2007; 2;(5 Suppl.);S2-3. | Article | PubMed

61. Nguyen CL, Scott WJ, Goldberg M: Radiofrequency ablation of lung malignancies. Ann Thorac Surg 2006; 82;(1.);365-71. | Article | PubMed

62. Iguchi T, Hiraki T, Gobara H, Mimura H, Fujiwara H, Tajiri N, et al.: Percutaneous radiofrequency ablation of lung tumors close to the heart or aorta: evaluation of safety and effectiveness. J Vasc Interv Radiol 2007; 18;(6.);733-40. | Article | PubMed

63. Feng W, Liu W, Li C, Li Z, Li R, Liu F, et al.: Percutaneous microwave coagulation therapy for lung cancer. Zhonghua Zhong Liu Za Zhi 2002; 24;(4.);388-90. | PubMed

64. Wright AS, Lee FT, Jr., Mahvi DM: Hepatic microwave ablation with multiple antennae results in synergistically larger zones of coagulation necrosis. Ann Surg Oncol 2003; 10;(3.);275-83. I Article I PubMed

65. Wright AS, Sampson LA, Warner TF, Mahvi DM, Lee FT, Jr.: Radiofrequency versus microwave ablation in a hepatic porcine model. Radiology 2005; 236;(1.);132-9. | Article | PubMed

66. Skinner MG, lizuka MN, Kolios MC, Sherar MD: A theoretical comparison of energy sources--microwave, ultrasound and laser--for interstitial thermal therapy. Phys Med Biol 1998; 43;(12.);3535-47. | Article | PubMed

67. Shock SA, Meredith K, Warner TF, Sampson LA, Wright AS, Winter TC, 
3rd, et al.: Microwave ablation with loop antenna: in vivo porcine liver model. Radiology 2004; 231;(1.);143-9. | Article | PubMed

68. Stauffer PR, Rossetto F, Prakash M, Neuman DG, Lee T: Phantom and animal tissues for modelling the electrical properties of human liver. Int J Hyperthermia 2003; 19;(1.);89-101. | Article | PubMed

69. Brace CL, Hinshaw JL, Laeseke PF, Sampson LA, Lee FT, Jr.: Pulmonary thermal ablation: comparison of radiofrequency and microwave devices by using gross pathologic and CT findings in a swine model. Radiology 2009; 251;(3.);705-11. | Article | PubMed Abstract | PubMed Full Text

70. Rhim H, Dodd GD, 3rd: Radiofrequency thermal ablation of liver tumors. J Clin Ultrasound 1999; 27;(5.);221-9. | Article I PubMed

71. Gillams A: Minimally invasive treatment for liver and lung metastases in colorectal cancer. BMJ 2007; 334;(7602.);1056-7. | Article | PubMed Abstract | PubMed Full Text

72. Gillams A: Tumour ablation: current role in the liver, kidney, lung and bone. Cancer Imaging 2008; 8 Spec No A;(S1-5. | Article | PubMed Abstract | PubMed Full Text

73. Wolf FJ, Beland MD: Thermal ablation: clinical applications, safety, and efficacy. Med Health R I 2009; 92;(12.);407-11. I PubMed

74. Simon CJ, Dupuy DE, DiPetrillo TA, Safran HP, Grieco CA, Ng T, et al.: Pulmonary radiofrequency ablation: long-term safety and efficacy in $\mathbf{1 5 3}$ patients. Radiology 2007; 243;(1.);268-75. | Article I PubMed

75. VanSonnenberg E, Shankar S, Morrison PR, Nair RT, Silverman SG, Jaklitsch MT, et al.: Radiofrequency ablation of thoracic lesions: part 2, initial clinical experience--technical and multidisciplinary considerations in 30 patients. AJR Am J Roentgenol 2005; 184;(2.);381-90. I Article | PubMed

76. Steinke K, Haghighi KS, Wulf S, Morris DL: Effect of vessel diameter on the creation of ovine lung radiofrequency lesions in vivo: preliminary results. J Surg Res 2005; 124;(1.);85-91. | Article | PubMed

77. Ambrogi MC, Fanucchi O, Lencioni R, Cioni R, Mussi A: Pulmonary radiofrequency ablation in a single lung patient. Thorax 2006; 61;(9.);828-9. | Article | PubMed Abstract | PubMed Full Text

78. McTaggart RA, Dupuy DE: Thermal ablation of lung tumors. Tech Vasc Interv Radiol 2007; 10;(2.);102-13. | Article | PubMed

79. Rose SC, Thistlethwaite PA, Sewell PE, Vance RB: Lung cancer and radiofrequency ablation. J Vasc Interv Radiol 2006; 17;(6.);927-51; quiz 51. | Article | PubMed

80. Battafarano RJ, Meyers BF, Guthrie TJ, Cooper JD, Patterson GA: Surgical resection of multifocal non-small cell lung cancer is associated with prolonged survival. Ann Thorac Surg 2002; 74;(4.);988-93; discussion 93-4. | Article | PubMed

81. Brace CL: Radiofrequency and microwave ablation of the liver, lung, kidney, and bone: what are the differences? Curr Probl Diagn Radiol 2009; 38;(3.);135-43. | Article | PubMed Abstract | PubMed Full Text

82. Wright AS, Sampson LA, Warner TF, Mahvi DM, Lee FT, Jr.: Radiofrequency versus microwave ablation in a hepatic porcine model. Radiology 2005; 236;(1.);132-9. | Article | PubMed

\section{Citation:}

Carrafiello G, Nocchi Cardim L, Floridi C, Piacentino F, Di Massa A, Ierardi AM and Fugazzola C: Patient selection - clinical and imaging criteria - for percutaneous lung malignancies ablation: a single centre experience and a literature review. journal of Cancer Therapeutics and Research 2012, 1:23.

http://dx.doi.org/10.7243/2049-7962-1-23 